$\sqrt{3}$

J. bio-sci. 15: 139-145, 2007

ISSN 1023-8654

http://www.banglajol.info/index.php/JBS/index

\title{
YIELD AND YIELD COMPONENTS OF BARLEY (HORDEUM VULGARE L.) IN RELATION TO SOWING TIMES
}

\author{
M Z Alam? , S A Haider and N K Paul \\ Department of Botany, University of Rajshahi, Rajshahi-6205, Bangladesh
}

\begin{abstract}
A field experiment was carried out to study the influence of sowing times on yield and yield components of barley (Hordeum vulgare L.). Seeds of four barley cultivars (BB 1, Karan 19, Karan 163 and Karan 351) were sown with four sowing times (5 November, 17 November, 29 November and 11 December). Most of the yield and yield components were significantly highest in 17 November sowing. Among the cultivars most of the characters showed their highest values in BB 1 and the lowest in Karan 19. Harvest index was found highest in Karan 351 and lowest in BB 1.
\end{abstract}

Key words: Barley, Sowing time, Yield.

\section{Introduction}

Barley (Hordeum vulgare L.) is a supplementary cereal crop after maize, wheat and rice in the world and third important cereal after rice and wheat in Bangladesh (FAO 1993-2002). Crop like barley requires far less water and can be cultivated in areas where irrigation water is less easily obtainable. The production of barley is gradually decreasing in Bangladesh (FAO 1993-2002). There are many reasons behind this decrease in production. In Bangladesh, farmers cultivate crops without considering proper sowing time. The actual cause of low yield is due to the effect of shorter growing period in the vegetative phase and steep rise in temperature at the grain filling stage (Nass et al. 1975). So, time of sowing of barley is a major limiting factor in Bangladesh.

Sowing time depends on weather, topography and harvesting time of the preceding crops. Seeding of barley is done in early November in the medium highland areas particularly northern part of Bangladesh. In these water deficit areas desertification is going on and agricultural production is very low but in the lowland areas, sowing is delayed even up to December because the land is occupied by 'Aman' Paddy or the land remains excessively moist after the removal of flood water.

Early November is usually dry, warm and rich in soil moisture but the temperature decreases sharply to the lowest level in early January when the crop is in the vegetative stage. The reproductive phase commences when the temperature starts rising and water shortage occurs in the soil profile at the later part of the season. In early growing season, barley plants suffer by excessive soil moisure resulting seedling damage, fertilizer leaching and long vegetative period.

On the contrary, late-planted barley experiences low temperature at seedling emergence and decreases physiological process and cause a greater yield decrease (Korovin and Mamaev 1983). Later on high temperature reduces duration of tillering, grain growth and crop productivity (Savin et al. 1997 and Wallwork

? Corresponding author : e-mail: zabotbd@yahoo.com 
et al. $1998 \mathrm{a}, \mathrm{b})$. Sowing at an appropriate time is necessary for ensuring maximum yield and that is why sowing time needs $\boldsymbol{b}$ be adjusted so that the crop germinates well and utilize the soil moisture stored in the soil profile effectively. Enormous efforts are, therefore, needed to recommending proper sowing time. The present experiment was set up to find out a suitable time of sowing for better performance of yield of barley under field condition.

\section{Materials and Methods}

The experiment was conducted in the research field of the Department of Botany, University of Rajshahi, Bangladesh. The soil of the experimental field was silty loam with $\mathrm{pH}$ of 6.6 . The total nitrogen was $0.06 \%$, organic matter $1.04 \%$, phosphorus $13.9 \mathrm{ppm}$, potassium 0.12 milliequivalent $/ 100 \mathrm{~g}$ soil, zinc $0.40 \mathrm{ppm}$ and sulphur $8.1 \mathrm{ppm}$. The experiment was conducted in a Randomized Block Design with three replications. Four cultivars of barley (BB 1, Karan 19, Karan 163 and Karan 351) were sown in four sowing dates [5 November (S1), 17 November (S2), 29 November (S3) and 11 December (S4)], Each plot consisted of 32 rows. Every replication plot was $8 \mathrm{~m}$ long and $6.5 \mathrm{~m}$ wide. A distance of $20 \mathrm{~cm}$ was maintained between rows and $5 \mathrm{~cm}$ between plants. Data from 6 randomly selected plants from middle rows of each plot were recorded at the time of final harvest.

\section{Results and Discussion}

Crop yield is a complex character depending upon a large number of environmental, morphological and physiological characters. In the present study, yield and yield components were significantly affected by sowing times.

Plant height is an important morphological character directly linked with the productive potential of plant in terms of grain yield. In the present investigation, significant reduction in plant height was noticed due to delay in sowing (Table 1). Similar results were also reported by Makki and Habib (1979) and KozlowskaPtaszynska (1993) in barley. Among the cultivars, BB 1 produced the tallest plant followed by Karan 351, Karan 163 and Karan 19.

Number of total tillers plant 1 is also another important character, which ensures higher yield. Delay in sowing reduced number of tillers plant- 1 as well in the present investigation (Table 1). These results are in agreement with Petr et al. (1979) and Makki and Habib (1979). Among the cultivars, BB 1 had the highest tiller number plant1 followed by Karan 351, Karan 163 and Karan 19.

Number of fertile tillers plant 1 is an important character, which ensured highest yield. Delay in sowing after 17 November reduced the fertile tillers plant1 in the present study (Table 1), which corroborated the findings of Noworolnik and Leszczynska (1997) and Chun et al. (2000). Among the cultivars, BB 1 produced the highest number of fertile tillers plant 1 followed by Karan 351, Karan 163 and Karan 19 in both the years.

Delay in sowing resulted reduction in extrusion length as well (Table 1). It might be due to the scarcity of soil moisture and low temperature at the later sowing dates.

Delay in sowing reduced the spike length in the present investigation (Table 1), which agreed with the findings of Abdel-Raouf et al. (1983b). Reduction of panicle length at the later sowing dates might be due to low temperature at the vegetative stage and scarce soil moisture as well.

Delay in sowing reduced number of spikelets spike-1 in the present study, which also agreed with the findings of Petr et al. (1979) and Noworolnik and Leszczynska (1997). Among the cultivars, BB 1 produced the highest number of spikelets spike-1 followed by Karan 351, Karan 163 and Karan 19. 
Table 1. Influence of different sowing times on yield and yield components of barley cultivars.

\begin{tabular}{|c|c|c|c|c|c|}
\hline Cultivars (C) & $\mathrm{S}_{1}$ & $\mathrm{~S}_{2}$ & $\mathrm{~S}_{3}$ & $\mathrm{~S}_{4}$ & C-Mean \\
\hline & \multicolumn{5}{|c|}{ Plant height (cm) } \\
\hline BB 1 & $93.79 \mathrm{a}$ & $91.09 \mathrm{a}$ & $85.27 \mathrm{a}$ & $76.04 \mathrm{a}$ & 86.55 \\
\hline Karan 19 & $74.36 \mathrm{c}$ & $71.65 \mathrm{c}$ & $65.82 d$ & $56.59 d$ & 67.11 \\
\hline Karan 163 & $79.55 b$ & $76.83 \mathrm{~b}$ & $71.01 \mathrm{c}$ & $61.78 \mathrm{c}$ & 72.29 \\
\hline Karan 351 & $80.11 b$ & $77.40 \mathrm{~b}$ & $71.59 b$ & $62.35 b$ & 72.86 \\
\hline S-Mean & 81.95 & 79.24 & 73.42 & 64.19 & 74.70 \\
\hline \multirow[t]{2}{*}{ LSD at $5 \%$} & $C=$ & 0.25 & $S=$ & 2.98 & \\
\hline & \multicolumn{5}{|c|}{ No. of total tillers (plant ${ }^{-1}$ ) } \\
\hline BB 1 & $5.5 \mathrm{a}$ & $5.5 \mathrm{a}$ & $4.3 \mathrm{a}$ & $2.9 \mathrm{a}$ & 4.5 \\
\hline Karan 19 & $4.4 \mathrm{C}$ & $4.8 \mathrm{~b}$ & $3.3 c$ & $2.3 b$ & 3.7 \\
\hline Karan 163 & $4.9 \mathrm{~b}$ & $5.1 b$ & $3.4 \mathrm{c}$ & $2.7 \mathrm{a}$ & 4.0 \\
\hline Karan 351 & $5.1 a b$ & $5.4 \mathrm{a}$ & $3.8 \mathrm{~b}$ & $2.8 \mathrm{a}$ & 4.3 \\
\hline S-Mean & 5.0 & 5.2 & 3.7 & 2.7 & 4.1 \\
\hline \multirow[t]{2}{*}{ LSD at $5 \%$} & $C=$ & 0.16 & $S=$ & 0.37 & \\
\hline & \multicolumn{5}{|c|}{ No. of fertile tillers (plant ${ }^{-1}$ ) } \\
\hline BB 1 & $4.1 \mathrm{a}$ & $4.2 \mathrm{a}$ & $4.1 \mathrm{a}$ & $3.2 \mathrm{a}$ & 3.9 \\
\hline Karan 19 & $3.3 b$ & $3.5 \mathrm{c}$ & $3.2 \mathrm{C}$ & $2.3 \mathrm{C}$ & 3.1 \\
\hline Karan 163 & $3.1 \mathrm{~b}$ & $3.6 \mathrm{c}$ & $3.0 \mathrm{~d}$ & $2.4 \mathrm{C}$ & 3.0 \\
\hline Karan 351 & $3.9 \mathrm{a}$ & $3.9 \mathrm{~b}$ & $3.7 b$ & $2.9 \mathrm{~b}$ & 3.6 \\
\hline S-Mean & 3.6 & 3.8 & 3.5 & 2.7 & 3.4 \\
\hline \multirow[t]{2}{*}{ LSD at $5 \%$} & $C=$ & 0.12 & $S=$ & 0.15 & \\
\hline & \multicolumn{5}{|c|}{ Extrusion length (cm) } \\
\hline BB 1 & $5.07 \mathrm{a}$ & $4.77 \mathrm{a}$ & $4.45 \mathrm{a}$ & $4.13 \mathrm{a}$ & 4.60 \\
\hline Karan 19 & $1.48 d$ & $1.27 \mathrm{~d}$ & $1.03 \mathrm{~d}$ & $0.81 \mathrm{~d}$ & 1.15 \\
\hline Karan 163 & $2.32 \mathrm{c}$ & $2.01 \mathrm{C}$ & $1.68 \mathrm{c}$ & $1.36 \mathrm{c}$ & 1.84 \\
\hline Karan 351 & $3.31 b$ & $3.00 \mathrm{~b}$ & $2.66 \mathrm{~b}$ & $2.34 \mathrm{~b}$ & 2.83 \\
\hline S-Mean & 3.04 & 2.76 & 2.46 & 2.16 & 2.60 \\
\hline \multirow[t]{2}{*}{ LSD at $5 \%$} & $C=$ & 0.08 & $S=$ & 0.46 & \\
\hline & \multicolumn{5}{|c|}{ Spike length (cm) } \\
\hline BB 1 & $18.41 \mathrm{a}$ & $16.93 \mathrm{a}$ & $13.23 \mathrm{a}$ & $9.51 \mathrm{a}$ & 14.52 \\
\hline Karan 19 & $14.83 \mathrm{C}$ & $13.35 \mathrm{c}$ & $9.65 \mathrm{c}$ & $5.95 \mathrm{C}$ & 10.95 \\
\hline Karan 163 & $15.64 \mathrm{~b}$ & $14.15 b$ & $10.47 b$ & $6.73 \mathrm{~b}$ & 11.75 \\
\hline Karan 351 & $15.79 \mathrm{~b}$ & $14.30 \mathrm{~b}$ & $10.59 \mathrm{~b}$ & $6.88 \mathrm{~b}$ & 11.89 \\
\hline S-Mean & 16.17 & 14.68 & 10.98 & 7.27 & 12.27 \\
\hline LSD at $5 \%$ & $C=$ & 0.11 & $S=$ & 3.29 & \\
\hline
\end{tabular}


Table 1. (Continued) Influence of different sowing times on yield and yield components of barley cultivars.

\begin{tabular}{|c|c|c|c|c|c|}
\hline Cultivars $(\mathrm{C})$ & $\mathrm{S}_{1}$ & $\mathrm{~S}_{2}$ & $\mathrm{~S}_{3}$ & $\mathrm{~S}_{4}$ & C-Mean \\
\hline & \multicolumn{5}{|c|}{ No. of spikelets (spike-1) } \\
\hline BB 1 & $15.4 \mathrm{a}$ & $16.1 \mathrm{a}$ & $13.4 \mathrm{a}$ & $13.9 \mathrm{a}$ & 14.7 \\
\hline Karan 19 & $13.1 d$ & $13.8 \mathrm{~d}$ & $11.3 d$ & $11.9 \mathrm{~d}$ & 12.5 \\
\hline Karan 163 & $13.9 \mathrm{c}$ & $14.6 \mathrm{c}$ & $11.8 \mathrm{C}$ & $12.4 \mathrm{C}$ & 13.2 \\
\hline Karan 351 & $14.8 b$ & $15.4 \mathrm{~b}$ & $12.6 \mathrm{~b}$ & $13.3 b$ & 14.0 \\
\hline S-Mean & 14.3 & 15.0 & 12.3 & 12.9 & 13.6 \\
\hline \multirow[t]{2}{*}{ LSD at $5 \%$} & \multicolumn{2}{|c|}{$C=0.14$} & \multicolumn{2}{|c|}{$S=0.68$} & \\
\hline & \multicolumn{5}{|c|}{ Total dry matter (g plant ${ }^{-1}$ ) } \\
\hline BB 1 & $14.94 \mathrm{a}$ & $13.44 \mathrm{a}$ & $11.93 \mathrm{a}$ & $9.03 \mathrm{a}$ & 12.33 \\
\hline Karan 19 & $9.24 \mathrm{C}$ & $8.63 d$ & $7.72 \mathrm{c}$ & $5.87 \mathrm{C}$ & 7.87 \\
\hline Karan 163 & $9.53 \mathrm{C}$ & $9.28 \mathrm{C}$ & $7.81 \mathrm{c}$ & $6.01 \mathrm{c}$ & 8.16 \\
\hline Karan 351 & $11.36 \mathrm{~b}$ & $11.03 \mathrm{~b}$ & $9.01 \mathrm{~b}$ & $6.87 \mathrm{~b}$ & 9.57 \\
\hline S-Mean & 11.27 & 10.60 & 9.12 & 6.95 & 9.48 \\
\hline \multirow[t]{2}{*}{ LSD at $5 \%$} & \multicolumn{2}{|c|}{$C=0.21$} & \multicolumn{2}{|c|}{$S=2.34$} & \\
\hline & \multicolumn{5}{|c|}{ 1000-grain weight $(\mathrm{mg})$} \\
\hline BB 1 & $34.5 \mathrm{a}$ & $35.5 \mathrm{a}$ & $33.5 \mathrm{a}$ & $29.5 \mathrm{a}$ & 33.3 \\
\hline Karan 19 & $30.2 \mathrm{c}$ & $30.5 d$ & $29.7 \mathrm{c}$ & $27.3 \mathrm{C}$ & 29.4 \\
\hline Karan 163 & $30.3 \mathrm{c}$ & $31.2 \mathrm{c}$ & $30.1 \mathrm{c}$ & $27.9 \mathrm{bc}$ & 29.9 \\
\hline Karan 351 & $32.1 \mathrm{~b}$ & $32.8 b$ & $31.2 b$ & $28.3 b$ & 31.1 \\
\hline S-Mean & 31.8 & 32.5 & 31.1 & 28.3 & 30.9 \\
\hline \multirow[t]{2}{*}{ LSD at $5 \%$} & \multicolumn{2}{|c|}{$C=0.32$} & \multicolumn{2}{|c|}{$\mathrm{S}=2.47$} & \\
\hline & \multicolumn{5}{|c|}{ Harvest index (\%) } \\
\hline BB 1 & $24.35 d$ & $28.01 \mathrm{c}$ & $24.01 b$ & $20.98 \mathrm{~b}$ & 24.34 \\
\hline Karan 19 & $25.51 \mathrm{c}$ & $28.95 b$ & $23.78 \mathrm{~b}$ & $19.79 \mathrm{C}$ & 24.51 \\
\hline Karan 163 & $26.31 b$ & $28.70 \mathrm{bc}$ & $24.09 \mathrm{~b}$ & $20.66 b$ & 24.94 \\
\hline Karan 351 & $27.41 \mathrm{a}$ & $30.11 \mathrm{a}$ & $27.14 \mathrm{a}$ & $22.63 \mathrm{a}$ & 26.82 \\
\hline S-Mean & 25.89 & 28.94 & 24.76 & 21.01 & 25.15 \\
\hline \multirow[t]{2}{*}{ LSD at $5 \%$} & \multicolumn{2}{|c|}{$C=0.38$} & \multicolumn{2}{|c|}{$S=2.02$} & \\
\hline & \multicolumn{5}{|c|}{ Grain yield (kg/ha) } \\
\hline BB 1 & $3667.9 \mathrm{a}$ & $3800.7 \mathrm{a}$ & $2913.8 \mathrm{a}$ & $1946.3 \mathrm{a}$ & 3082.2 \\
\hline Karan 19 & $2438.4 d$ & $2538.9 d$ & 1929.7 C & $1224.3 d$ & 2032.8 \\
\hline Karan 163 & 2581.5 c & $2700.0 \mathrm{C}$ & 1968.7 c & $1298.7 \mathrm{C}$ & 2137.2 \\
\hline Karan 351 & $3163.2 \mathrm{~b}$ & $3354.5 \mathrm{~b}$ & $2532.5 \mathrm{~b}$ & $1605.5 \mathrm{~b}$ & 2664.0 \\
\hline S-Mean & 2962.8 & 3098.5 & 2336.2 & 1518.7 & 2479.0 \\
\hline LSD at $5 \%$ & \multicolumn{2}{|c|}{$C=55.9$} & \multicolumn{2}{|c|}{$S=705.9$} & \\
\hline
\end{tabular}

In a column, means followed by a common letter are not significantly different at the $5 \%$ level by DMRT. 
Total dry matter influences other yield components. In the present investigation, early sowing gave higher TDM (Table 1), which are in agreement with Bonari and Macchia (1980) and Abdel-Raouf et al. (1983a).

1000-grain weight is an important yield component as stated by Petr et al. (1979). In the present investigation, 1000-grain weight was highest in S2 and thereafter declined with delay in sowing (Table 1). Similar results were reported in barley by many workers, such Noworolnik (1989 a,b) and Conry and Hegarty (1992). Among the cultivars, BB 1 had the highest 1000-grain weight irrespective of sowing dates.

Harvest index is the proportion of commercial yield and biological yield. As grain yield was higher in S2, harvest index was also found to be higher in S2 and followed by S1, S3 and S4 in the present investigation (Table 1). Among the cultivars, harvest index was in the order of Karan 351> Karan 163> Karan 19> and BB 1 , respectively.

Grain yield is a complex character depending upon a large number of environmental, morphological and physiological characters. Grain yields also depend upon other yield components. In the present investigation, 17 November (S2) sown crops produced higher grain yield followed by 5 November (S1), 29 November (S3) and 11 December (S4). Generally, delay in sowing reduced grain yield. Similar results were reported in barley by Kozlowska-Ptaszynska (1993), Ekeberg (1994) and Noworolnik and Leszczynska (1997). Among the cultivars, BB 1 had the highest grain yield and was followed by Karan 351, Karan 163 and Karan 19.

In the present investigation, yield and yield components were more or less reduced by late sowing as compared to 5 November and 17 November. Usanova (1985) reported that a delay of 10 days in sowing decreased the yield by $0.5-0.51$ tha or 12.9 and $14.6 \%$. The main reason for the yield reduction was low utilization of photosynthetically active radiation during the first 1.5 months after sowing, the decrease in photosynthetic activity of plants during grain filling and maturation and the acceleration of plant development by 3-6 days, all of which decreased the 1000-grain weight.

Ekeberg (1994) reported that, on average, cereal grain yield decreased by $21 \mathrm{~kg} / \mathrm{ha}$ with each day delay in sowing. Nass et al. (1975) reported yield reduction for late sowing due to shorter growing period in the vegetative phase and steep rise in temperature at the grain filling stage. High temperatures are known to hasten spike development from floral initiation to anthesis, and also have been found to reduce the number of spikelets formed per spike (Dawson and Wardlaw 1989). Frank et al. (1992) reported that fertile spikelet number decreased significantly in barley $\mathrm{cv}$. Azure as temperature increased from $16^{\circ} \mathrm{C}$ to $18^{\circ} \mathrm{C}$. High temperature also hastened phenological development (Boonchoo et al. 1998).

In the present investigation, 29 November (S3) and 11 December (S4) also experienced shorter growing period and steep rise in temperature at the later stages of growth. Miralles et al. (2000) reported that increased duration of stem elongation period in wheat and barley increased floret fertility and grain number. On the other hand, shorter photoperiods reduced the rate of floret development. Green et al. (1985) found linear decrease in maximum grain yield due to delayed sowing. They also found that early sowing induced faster production of tillers and consequently gave higher maximum tillers and tended to accumulate dry matter at a faster rate and provided the highest grain yield led by optimum temperature during the growth period. High temperature at the later stages of growth also reduced grain yield in 29 November (S3) and 11 December (S4) in the present study. High temperature at the later stages of growth (particularly in grain filling period) reduced kernel weight, which resulted lower grain yield. Similar results were reported by Wallwork et al. (1998 a,b) and Savin and Nicolas (1999). 
The overall results indicated that higher grain yield was obtained from 17 November (S2) sown crops. It might be due to cumulative effect of optimum temperature at the vegetative and reproductive stages that provided highest number of fertile tillers plant1, highest number of spikelets spike-1, and highest 1000-grain weight. On the other hand, the lowest yield obtained from S3 and S4 crops was attributed to lower values of the above-mentioned characters due to lower temperature at the early vegetative stage and sharp rise in temperature at the reproductive stage, which eventually shortened the growth period.

\section{References}

Abdel-Raouf M S, Kandil A, Gheith E M S and Mahros N (1983a) Associations between growth attributes of barley and grain yield under different seeding dates. Ann. Agril. Sci. Moshtohor. 19(1): 45-55.

Abdel-Raouf, M S Kandil, A Gheith E M S and Mahros N (1983b) Barley grain yield and its components as affected by seeding and harvesting dates. Ann. Agril. Sci. Moshtohor. 19(1): 57-67.

Bonari E and Macchia M (1980) Autumn and spring barley cultivars and sowing date. Sementi Elette. 26(1): 23-29.

Boonchoo S, Fukai S and Hetherington. E S (1998) Barley yield and grain protein concentration as affected by assimilate and nitrogen availability. Aust. J. Agril. Res. 49: 695-706.

Chun J U, Choi H S and Nam J H (2000) Effects of seeding date and rate on growth and yield of barley cultivar 'Duwonchapssalbori' in southern region. Korean J. Crop Sci. 45(1): 14-19.

Conry M J and Hegarty A (1992) Effect of sowing date and seed rate on the grain yield and protein content of winter barley. J. Agril. Sci. 118(3): 279-287.

Dawson I A and Wardlaw I F (1989) The tolerance of wheat to high temperatures during reproductive growth. III. Booting to anthesis. Aust. J. Agril. Res. 40: 965-980.

Ekeberg E (1994) Trials with different sowing dates in 1985-89. Norsk Landbruksforsking. 8(2):155-175.

FAO (1993-2002) FAOSTAT: Statistics database. [Online.] [Subset Production within Agriculture database. http://apps.fao.org

Frank A B, Bauer A and Black A L (1992) Effects of air temperature and fertilizer nitrogen on spike development in spring barley. Crop Sci. 32(3): 793-797.

Green C F, Furmston D T and Ivins J D (1985) Effect of time of sowing and the yield of winter barley (Hordeum distichum L. cv. Igri.) J. Agril. Sci. Camb. 104: 405-411.

Korovin A I and Mamaev E V (1983) Effect of lowered temperatures on yield and vegetative growth period of oats and barley. Nauchno-tekhnicheskii Byulleten' Vsesoyuznogo Ordena Lenina i Ordena Druzhby Narodov Nauchnoissledovatel'skogo Instituta Rastenievodstva Imeni N I Vavilova. 132: 30-33.

Kozlowska-Ptaszynska Z (1993) Changes in the structure and architecture of the plant canopy of two-and six-rowed spring barley cultivars as influenced by sowing date. Pamietnik Pulawski. 102: 53-64.

Makki Y M and Habib M M (1979) Effect of sowing date on yield and yield components of barley grown in the central region of Saudi Arabia. Proceedings of the Saudi Biol. Soc. 3: 25-34.

Miralles D J, Richards R A and Slafer G A (2000) Duration of the stem elongation period influences the number of fertile florets in wheat and barley. Aust. J Plant Physiol. 27(10): 931-940. 
Nass H G ,Johnston H W, Macleod J A and Sterling D E (1975) Effect of seeding date, seed treatment and foliar sprays on yield and other agronomic characters of wheat, oats and barley. Canadian J. Plant Sci. 55: 41-47.

Noworolnik K (1989a) Sowing date effect on spring barley grain yield and its structure. Biuletyn Instytutu Hodowli $i$ Aklimatyzacji Roslin. 169: 177-181.

Noworolnik K (1989b) Response of winter barley to soil conditions, nitrogen application, sowing date and sowing rate. Pamietnik Pulawski. 94: 237-244.

Noworolnik K and Leszczynska D (1997) Yields of spring barley cultivars and lines depending on sowing date. Biuletyn Instytutu Hodowli i Aklimatyzacji Roslin. 201: 225-230.

Petr J, Hnilica P and Schmidt J (1979) Yield formation in spring barley: tillering, ear formation and grains per ear. Rostlinna Vyroba. 25(4): 433-444.

Savin R and Nicolas M E (1999) Effects of timing of heat stress and drought on growth and quality of barley grains. Aust. J. Agril. Res. 50(3): 357-364.

Savin R, Stone P J Nicolas M E and Wardlaw I F (1997) Grain growth and malting quality of barley. 2. Effects of temperature regime before heat stress. Aust. J. Agril. Res. 48(5): 625-634.

Usanova Z I (1985) Yield formation of barley and oats sown at different dates. Izvestiya Timiryazevskoi Sel'skokhozyaistvennoi Akademii. 6: 27-38.

Wallwork M A B, Logue S J, MacLeod L C and Jenner C F (1998a) Effects of a period of high temperature during grain filling on the grain growth characteristics and malting quality of three Australian malting barleys. Aust. J. Agril. Res. 49(8): 1287-1296

Wallwork M A B, Logue S J, MacLeod L C and Jenner C F (1998b). Effect of high temperature during grain filling on starch synthesis in the developing barley grain. Aust. J. Plant Physiol. 25(2): 173-181. 